\title{
Note on the Morphology of the Sperm Storage Tubules in the Polygynandrous Alpine Accentor, Prunella collaris
}

\author{
Akira Chiba* and Masahiko Nakamura** \\ Key words : Sperm storage tubules (SSTs), Morphological features, Alpine \\ Accentor (Prunella collaris), Polygynandrous mating system, Sperm competition. \\ キーワード：精子貯留腺, 形態学的様相, イワヒバリ, 多夫多妻制配偶システム, \\ 精子競争.
}

Sperm storage tubules (SSTs) are known as the main sperm storage sites in female birds after copulation (Howarth 1974, Birkhead 1988). Usually, they are found at the junction of the uterus and vagina. Previous studies on a wide range of avian species including both domestic and wild birds (Gilbert 1979, Hatch 1983, Shugart 1988, Briskie \& Montgomerie 1993) showed that the SSTs may be ubiquitous among birds and contributed to our understanding of their significance in physiological and ecological aspects of bird reproduction. Recently, interest in the SSTs has been focused on their role in sperm competition, but there is little evidence for adaptation in the sperm storage organ of female birds (Birkhead \& Møller 1992, Briskie \& Montgomerie 1993). Various aspects of sperm storage in the SSTs have been examined in detail, mainly in monogamous birds including the domesticated Zebra Finch, Taeniopygia guttata (Birkhead et al. 1989, 1990). However, more information about the number and size of SSTs in a greater range of species is needed to examine the adaptive significance of SSTs in female birds.

Previous studies (Davies et al. 1995, Nakamura 1990a, 1998a, b) showed that the Alpine Accentor, Prunella collaris, is a polygynandrous species. In the breeding season, the male bird has very big testes and apparently the largest cloacal protuberance (effective sperm storage) for its body size of any known bird, probably reflecting strong sperm competition. The female also has a unique cloacal protuberance which is colored scarlet around the vent and is displayed before mating (Nakamura 1990a). In fact, female Accentors have a high copulation rate, i.e., they copulate with several males more than 100 times until the last egg of the clutch is laid (Nakamura 1998b). Information on the anatomy of the SSTs in polygynandrous passerines is still limited (Birkhead et al. 1991 on a congeneric species, the Dunnock, P. modularis; Briskie 1993 on the Smith's Longspur, Calcarius pictus), and nothing is known about sperm storage in the Alpine Accentor. The present short communication reports morphological features of the SSTs (number, size, sperm storage capacity, and histology) in the polygynandrous Alpine Accentor as a contribution to the comparative study of SSTs in relation to adaptation and tactics in the

Received 12 October 2000, Revised 18 December 2000, Accepted 19 December 2000.

* Department of Biology, Nippon Dental University School of Dentistry at Niigata, Niigata 951-8580, Japan. E-mail: chiba@ngt.ndu.ac.jp.

** Laboratory of Animal Ecology, Department of Biology, Joetsu University of Education, 1 Yamayasikimachi, Joetsu-shi, Niigata 943-8512, Japan. 
mating system of birds.

Two females (specimens A and B) and one male (specimen C) of the Alpine Accentor were used in this study. Specimen A was a beta female (i.e., second in the female hierarchy) in a group of three females, and displayed a prominent cloacal lip, which indicates she was soliciting matings. Specimen B was collected during the incubation period and was a gamma female (third in the female hierarchy in a group of three females) with a regressing protuberance, apparently showing no solicitation for matings. Thus, the ovary was developed in specimen A, but not in specimen B (Table 1). Specimen C was an alpha male in a group of four males and had a large cloacal protuberance $(14.0 \mathrm{~mm}$ in maximum diameter). All of them were collected (under permission of Environmental Agency) during the breeding season on the summit of Mt. Norikura, Nagano Pref., Japan $\left(36^{\circ} 06^{\prime} \mathrm{N}, 137^{\circ} 33^{\prime} \mathrm{E}, 2,600-3,026 \mathrm{~m}\right.$ above sea level) and killed by deep anesthesia with chloroform. After measurement, their bodies were dissected and immersed in $5 \%$ buffered formaldehyde for one or two days. Their genital organs were dissected out and re-fixed with freshly prepared aldehyde solutions: $5 \%$ buffered formaldehyde for light microscopy or Karnovsky's fluid for electron microscopy. The utero-vaginal region of the oviduct was cut longitudinally, and the number of primary mucosal folds was counted. Then, each fold was carefully isolated by cutting with a razor blade, put on a glass slide, and observed as a whole mount preparation under a light microscope. Selected tissue samples were further processed for routine histology and cytology. Paraffin sections cut at $8-\mu \mathrm{m}$ thickness were stained with Mayer's hematoxylin-eosin and examined with the light microscope. Ultra-thin sections were cut with a diamond knife, stained with uranyl acetate and lead citrate, and viewed under a JEOL 1200 EX electron microscope. Semi-thin sections were stained with toluidine blue in borax for light microscopic examination. For measurement of sperm length, a piece of seminal glomera was picked out from the male cloacal protuberance, and the semen was diluted with a few drops of

Table 1. Summary of morphological data on the sperm storage tubules (SSTs) in female Alpine Accentors, with measurements of the ovary. Specimens A and B were sacrificed on 14 June and 7 July, 1999, respectively. Means are given \pm SD, and sample sizes are in parentheses.

\begin{tabular}{lcc}
\hline \multicolumn{1}{c}{ Measurements } & \multicolumn{2}{c}{ Specimen } \\
\cline { 2 - 3 } & A & B \\
\hline No. of mucosal fold per female & 14 & 13 \\
No. of SST per mucosal fold & Unknown & $73.4 \pm 27.5(13)$ \\
Total no. of SST per female & $1,027^{*}$ & 954 \\
Percent SST branched & unknown & $0.14(693)$ \\
Length of SST $(\mu \mathrm{m})$ & $265.0 \pm 40.6(15)$ & $117.1 \pm 33.4(100)$ \\
Width of SST $(\mu \mathrm{m})$ & $64.0 \pm 6.3(15)$ & $41.3 \pm 5.8(100)$ \\
Sperm no. per SST & $49.4 \pm 64.0(10)$ & Unknown \\
Body mass $(\mathrm{g})$ & 39.1 & 37.8 \\
Ovarian weight $(\mathrm{mg})$ & 965 & 15 \\
Maximum size of ovarian follicles $(\mathrm{mm})$ & 10.5 & 1.5 \\
\hline
\end{tabular}

* Estimated value. 
0.1 M phosphate buffer and examined with the light microscope equipped with an ocular micrometer.

The SSTs of the female Alpine Accentor were found in the mucosal folds of the utero-vaginal junction (Fig. 1a). The total number of SSTs in specimen B was estimated to be 954 by summing up the number of the tubules in each of 13 primary mucosal folds.

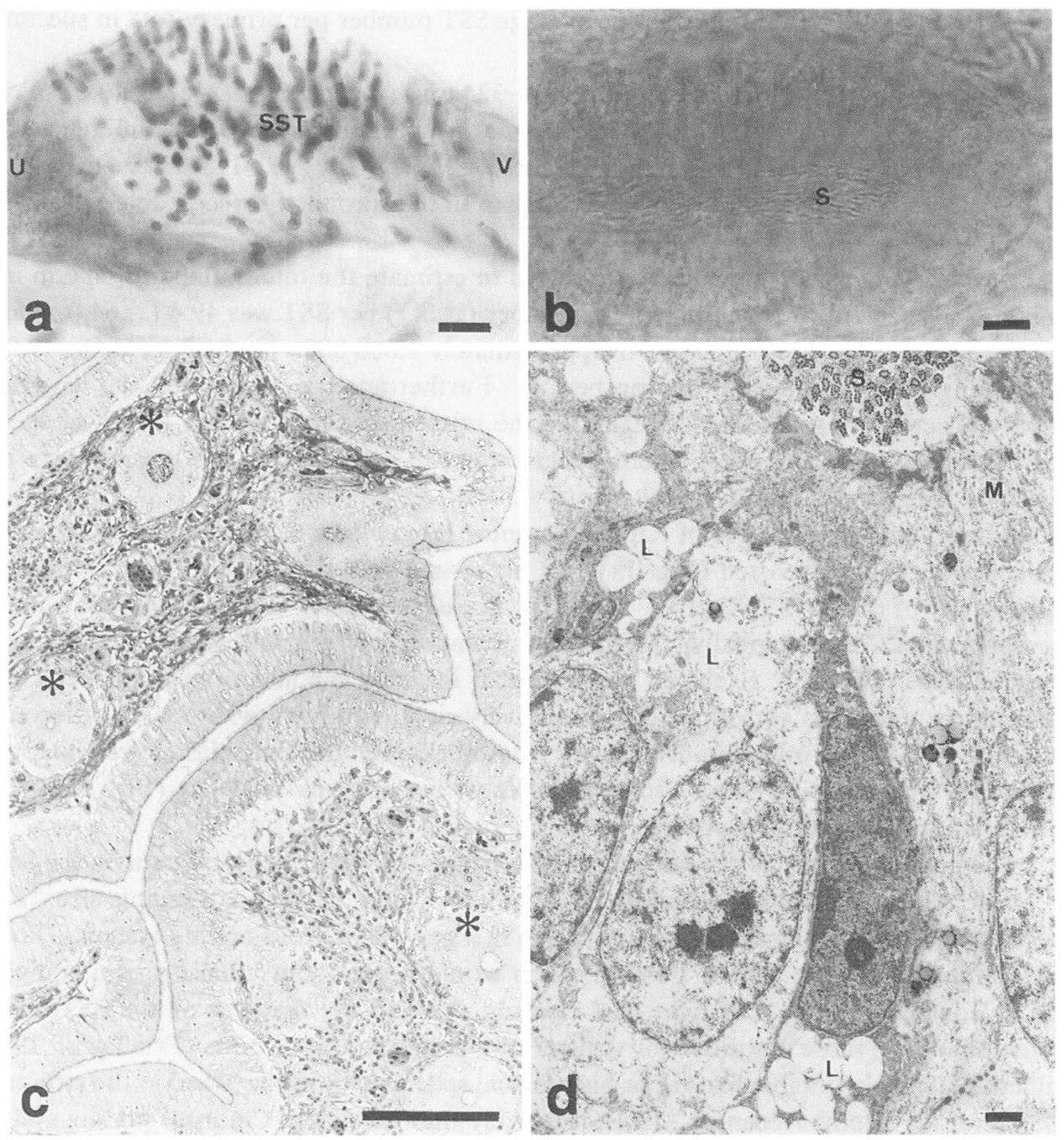

Fig. 1. Sperm storage tubules (SST) of a female Alpine Accentor, Prunella collaris. a, Low-power view of an isolated primary fold at the junction of the uterus (U) and the vagina (V). b, Detail of an SST containing sperm (S). c, Semi-thin section of primary folds showing SST (asterisks) with or without sperm. d, Electron micrograph of the epithelial cells comprising SST. M, mitochondria; L, lipid droplets; S, sperm in the luminal cavity. Scale bar (100 $\mu \mathrm{m}$ in $1 \mathrm{a}$ and $1 \mathrm{c} ; 10 \mu \mathrm{m}$ in $1 \mathrm{~b} ; 1 \mu \mathrm{m}$ in 1d). Figs. $1 \mathrm{~b}$ and 1c (Specimen A), Figs. 1a and 1d (Specimen B). 
The SST number varied among the folds, ranging from 36 to 115 , and the average number was 73.4 (13 primary folds censused, Table 1). However, it was technically difficult to estimate the total number of SSTs of specimen A collected during the copulation period, because the tubules did not offer good contrast to count them accurately under the light microscope, due to well-developed connective and glandular tissues within the folds. Nevertheless, its SST number may be estimated as 1,027 , if the number of primary folds of specimen A (14) is multiplied by the average SST number per primary fold in specimen B (73.4, see Table 1).

The length of SSTs ranged from $200-325 \mu \mathrm{m}$ (mean $\pm \mathrm{SD}=265.0 \pm 40.6 \mu \mathrm{m}$ ) in specimen $A$ and $60-270 \mu \mathrm{m}(117.1 \pm 33.4 \mu \mathrm{m})$ in specimen $\mathrm{B}$, and the difference was significant (two-tailed Mann-Whitney $U$-test, $z=-6.17, P<0.0001$ ). The width of the SSTs was significantly larger in specimen A than in the specimen $B$ (see Table $1, z=6.35$, $P<0.0001)$.

In spite of the small sample size, we tried to estimate the total number of sperm in a female. In specimen $A$, the mean sperm number $( \pm S D)$ per SST was 49.4 ( \pm 64.0 , range, 0-225, see Table 1). Since there were approximately 1,000 SSTs per female, about 49,000 sperm may be stored during mating period. Furthermore, we measured the length of sperm collected in specimen $\mathrm{C}$ to examine the relationship between the length of sperm and the length of SSTs. Mean sperm length was $120.9 \pm 1.3 \mu \mathrm{m}(n=50)$, and mean tail length of the sperm was $105.1 \pm 0.9 \mu \mathrm{m}(n=50)$.

In morphology, the SSTs of Alpine Accentor resembled a sausage in shape and some of them were slightly twisted (Fig. 1a). At higher magnification, sperm were recognized in the cavity of the SSTs (Fig. 1b). The incidence of branching SSTs was quite low in the present species. Histologically, the SST was composed of a single layer of non-ciliated epithelial cells (Fig. 1c). Each cell was columnar in shape and had an ovoid nucleus with a prominent nucleolus surrounded by a relatively rich cytoplasm, where were observed a moderate number of mitochondria, many ribosomes, granular endoplasmic reticula, and occasional lysosome-like dense bodies together with many lipid droplets (Fig. 1d). The luminal end of the cell was provided with microvilli.

The present paper has provided the first histological and cytological data on the SSTs in female Alpine Accentors, although the data were based on the small sample size. This species exhibits a high incidence of copulation in a polygynandrous mating system (Davies et al. 1995, Nakamura 1990a, 1998b), which would bring about intense sperm competition. However, the overall light and electron microscopic features of the SSTs were closely similar to those described for various non-polygynandrous birds (Frieß et al. 1978, Gilbert 1979). No notable feature or histological specialization was found in the structure of SSTs of the Alpine Accentor. Thus, it is likely that the polygynandrous mating system does not necessarily result in more sperm storage sites in the female nor affect the histological design of the SSTs.

The number of SSTs in this species was less than that reported in other polygynandrous species, e.g., the Smith's Longspur (mean $\pm S E=1,537 \pm 146$; Briskie 1993) and the Dunnock (1,398; Birkhead et al. 1991), and was nearly half of that found in the monogamous Lapland Longspur, C. lapponicus, (2,147 \pm 204 ; Briskie 1993) or the Yellow- 
headed Blackbird, Xanthocephalus xanthocephalus, (2,229 \pm 89 ; Briskie 1994). The SST number in Alpine Accentor was rather similar to that in the Great Tit, Parus major, (976士46; Kempenaers et al. 1994), although it was greater than that for the Blue Tit, $P$. caeruleus (779 \pm 67 ; Kempenaers et al. 1994). According to Briskie and Montgomerie (1993), the number of SSTs per female is correlated positively with body mass across species; i.e., larger species were found to have greater numbers of SSTs, but the birds showed no significant variation in the SST number over the breeding season (Briskie 1994, Pellatt 1998). Since the body mass of Alpine Accentor is 33.2-43.4 g (Nakamura 1990b), the estimated SST number (about 1,000) is rather less than that expected number (about 2,200) for birds of this body mass (Briskie 1993). Although the sample number was extremely limited in the present examination, females of the Alpine Accentor and two other polygynandrous passerines mentioned above do not appear to provide more sperm storage sites in response to increased sperm input by males.

The length of SSTs during the copulation period was more than twice that during the incubation period (Table 1). Similar results were obtained in other passerine birds (Briskie 1994). The length of SSTs in specimen A was similar to lengths reported for various passerine species, e.g., mean $\pm \mathrm{SE}=216.2 \pm 10.1 \mu \mathrm{m}$ in the Lapland Longspur

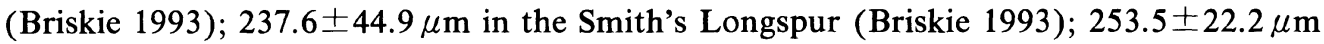
in the Blue Tit (Kempenaers et al. 1994); 270.6 $\pm 22.2 \mu \mathrm{m}$ in the Great Tit (Kempenaers et al. 1994); 188 $\pm 9 \mu \mathrm{m}$ in the Yellow-headed Balckbird (Briskie 1994), but obviously shorter than that in the Dunnock, $370.3 \pm 120.8 \mu \mathrm{m}$ (SE) and range of $164.0-645.7 \mu \mathrm{m}$ (Birkhead et al. 1991). The width of SSTs in the Alpine Accenter also fell within the range of that for other passerines (Shugart 1988, Briskie 1994, Kempenaers et al. 1994). The literature indicates that SST length varies considerably among the species and is strongly and positively correlated with sperm length, but not with female body weight (Briskie \& Montgomerie 1992, 1993). On the average, SST length was found to be twice the sperm length in the passerines (Briskie \& Montgomerie 1993). The present data on the Alpine Accentor (SST length, $265 \pm 40.6 \mu \mathrm{m}$; sperm length, $120.9 \pm 1.3 \mu \mathrm{m}$ ) are close to the average value. Thus, with respect to the SST length, female Alpine Accentors do not appear to provide more room for sperm storage (longer SSTs) as a consequence of having a polygynandrous mating system. In this examination, we estimated that tentative sperm storage capacity in the SSTs of the Alpine Accentor was about 49,000 sperm per female. This value is higher than that found in other polygynandrous species, e.g., the Smith's Longspur (39,000 sperm per female; Briskie 1993). However, because the size of the SST varies enormously over the season (Briskie 1994), it is difficult to estimate the accurate number of sperm stored in SSTs.

Our results indicate that the morphology, number, and size of SSTs in the female Accentor were similar to those for other passerines. Fertilization in birds typically occurs in the infundibulum during a brief "fertilization window" of only 15-30 minutes duration, shortly after ovulation (Howarth 1974). Because it is difficult for males to synchronize copulation with the fertilization window, SSTs may have evolved in birds for them to be successful at fertilization (Hatch 1983). Although males of many passerines including Alpine Accentors and Dunnocks do not adjust copulation to the ovulation of each egg, 
they can usually maintain constant surveillance of their partner and, during the fertile period, closely guard their females (Davies et al. 1995, Nakamura 1998a). Under these circumstances, it seems likely that females do not need to develop SSTs that can store numerous sperm because males can copulate whenever the female solicits. This explanation predicts that SSTs should be most developed in species which males can not efficiently guard their mates; i.e., the male or female feeds alone while the other guards the nest (e. g. raptors and colonial seabirds). Hatch (1983) suggests that SSTs allow the separation of the male and female colonial seabirds for several weeks before egg laying. As there are not yet enough comparable data, further accumulation of data on this subject is required.

\section{Acknowledgements}

The present study was partly supported by a grant (No. 10440232) from the Grants-in-Aid for Scientific Research (B) of the Japanese Ministry of Education, Science, and by the Global Environment Research Fund (F-1) of the Japan Environmental Agency. We thank Takayoshi Okamiya, Takayoshi Kiryu, and Takashi Yamamura for their help with the fieldwork.

\section{References}

Birkhead, T. R. 1988. Behavioral aspects of sperm competition in birds. Adv. Stud. Behav. 18: 35-72.

Birkhead, T. R. \& Møller, A. P. 1992. Sperm competition in birds: Evolutionary causes and consequences. Academic Press, London.

Birkhead, T. R., Hatchwell, B. J. \& Davies, N. B. 1991. Sperm competition and the reproductive organs of the male and female Dunnock Prunella modularis. Ibis 133: 306-311.

Birkhead, T. R., Hunter, F. M. \& Pellatt, E. J. 1989. Sperm competition in the Zebra Finch Taeniopygia guttata. Anim. Behav. 38: 935-950.

Birkhead, T. R., Pellatt, J. E. \& Hunter, F. M. 1990. Numbers and distribution of sperm in the uterovaginal sperm storage tubules of the Zebra Finch. Condor 92: 508-516.

Briskie, J. V. 1993. Anatomical adaptations to sperm competition in Smith's Longspurs and other polygynandrous passerines. Auk 110: 875-888.

Briskie, J. V. 1994. Seasonal patterns of sperm storage in the Yellow-headed Blackbird Xanthocephalus xanthocephalus. Ibis 136: 323-330.

Briskie, J. V., \& Montgomerie, R. 1992. Sperm size and sperm competition in birds. Proc. Roy. Soc. London. B. 247: 89-95.

Briskie, J. V., \& Montgomerie, R. 1993. Patterns of sperm storage in relation to sperm competition in passerine birds. Condor 95: 442-454.

Davies, N. B., Hartley, I. R., Hatchwell, B. J., Desrochers, A., Skeer, J. \& Nebel, D. 1995. The polygynandrous mating system of the Alpine Accentor, Prunella collaris. I. Ecological causes and reproductive conflicts. Anim. Behav. 49: 769-788.

Frieß, A. E., Sinowatz, F. \& Wrobel, K.-H. 1978. The uterovaginal sperm host glands of the Quail (Coturnix coturnix japonica). An ultrastructural and ultracytochemical study. Cell Tiss. Res. 191: 101-114.

Gilbert, A. B. 1979. Female genital organs. In Form and Function in Birds. King, A. S. \& Mclelland, J. (Eds.), Vol. 1, pp. 237-360. Academic Press, New York.

Hatch, S. A. 1983. Mechanism and ecological significance of sperm storage in the Northern Fulmar with reference to its occurrence in other birds. Auk 100: 593-600.

Howarth, B. 1974. Sperm storage as a function of the female reproductive tract. In the Oviduct and its 
Functions. Johnson, A. D. \& Foley, C. E. (Eds.), pp. 237-270. Academic Press, New York.

Kempenaers, B., Plompen, W. \& Briskie, J. V. 1994. Patterns of sperm storage in two species of tits. Ardea 82: 185-192.

Nakamura, M. 1990a. Cloacal protuberance and copulatory behavior of the Alpine Accentor (Prunella collaris). Auk 107: 284-295.

Nakamura, M. 1990b. Age determination in the Alpine Accentor Prunella collaris by discriminant analysis of morphological measurements. Jap. J. Ornithol. 39: 19-24.

Nakamura, M. 1998a. Multiple mating and cooperative breeding in polygynandrous Alpine Accentors. I. Competition among females. Anim. Behav. 55: 259-276.

Nakamura, M. 1998b. Multiple mating and cooperative breeding in polygynandrous Alpine Accentors. II. Male mating tactics. Anim. Behav. 55: 277-289.

Pellatt, E. J. 1998. Changes in the size and content of sperm storage tubules during the breeding cycle of the Zebra Finch Taeniopygia guttata. Ibis 140: 528-530.

Shugart, G. W. 1988. Uterovaginal sperm-storage glands in sixteen species with comments on morphological differences. Auk 105: 379-385.

\section{イワヒバリ精子貯留腺の形態学的様相}

乗鞍岳山頂部の繁殖地で捕獲された交尾期と抱卵期のイワヒバリ雌成鳥 2 個体を用いて精子 眝留腺を解剖学的に検索し，本種の特異な配偶システム（多夫多妻）との相関を検討した。本 種の精子眝留腺は，他種之同様，卵管の子宮・膣移行部粘膜璧内に存在し，非分岐性の細管之 して認められた。1 羽当たりの精子貯留腺総数は約 1,000 個と試算され, 各細管（腺）の平均長 は交尾期の個体で $265.0 \pm 39.0 \mu \mathrm{m}$ ，抱卵期の別個体で $116.5 \pm 33.5 \mu \mathrm{m}$ あった。また，腺腔に貯 留されている精子の数は，1 羽当たり 49,000 個と推定された。腺は単層の柱状上皮細胞からな り, 細胞頂端に多数の微䋐毛を持つが繊毛を欠き, 細胞質に脂質滴様空胞が多数存在するなど, その細胞・組織構造は鳥類で一般に見られるものと酷似していた。本種は乱婚で高い交尾頻度 を示すが, 配偶システムの異なる他種と較べて, 精子眝留腺が特に発達していたり, 形態学的 特化を示すようなことはなかった。

千葉 晃：日本歯科大学新潟歯学部生物学教室, テ951-8580 新潟市浜浦町 1-8.

E-mail: chiba@ngt.ndu.ac.jp

中村雅彦: 上越教育大学生物学教室動物生態学研究室, $\bar{\top} 943-8512$ 上越市山屋敷町 1 番地. E-mail: masahiko@juen.ac.jp 